\title{
Effect of Debittering Methods on the Minerals, and Phytochemical Properties of Orange (Citrus Sinensis) Seeds Flour
}

\author{
Eguono Ernest Emojorho ${ }^{1}$, Peter Isah Akubor ${ }^{2}$ \\ ${ }^{I}$ (Department of Food Science and Technology, University of Nigeria,Nsukka, Nigeria) \\ ${ }^{2}$ (Department of Food Science and Technology, Federal University, Wukari, Nigeria)
}

\begin{abstract}
The study out to determined the effect of debittering methods on the quality of flour prepared from orange seeds. Orange seeds were removed from orange fruits and then sundried at $30 \pm 2{ }^{\circ} \mathrm{C}$ for $8 \mathrm{~h}$. orange seeds (20kg) was soaked in water for 12 hours, boiled at different boiling period (40, 80, 120, and $160 \mathrm{~min})$ respectively. Boiled seeds were dehulled immediately to avoid spoilage, oven dried at $60{ }^{\circ} \mathrm{C}$ for 14 hours, grinded to increase its surface area and defatted using soxhlet extraction method with absolute ethanol. The mineral and phytochemicals results showed that the flours had iron $0.85 \mathrm{mg} / 100 \mathrm{~g}-18.54 \mathrm{mg} / 100 \mathrm{~g}$, zinc 0.34 $\mathrm{mg} / 100 \mathrm{~g}-0.67 \mathrm{mg} / 100 \mathrm{~g}$, calcium $18.23 \mathrm{mg} / 100 \mathrm{~g}-476.9 \mathrm{mg} / 100 \mathrm{~g}$, sodium $2.61 \mathrm{ppm}-8.27 \mathrm{ppm}$, potassium $6.28 \mathrm{ppm}-28.02 \mathrm{ppm}$, alkaloids $1.15 \%-6.95 \%$, saponins $0.0-0.38 \%$, flavonoids $0.55-29.17 \%$ and tannins $0.94 \mathrm{mg} / 100 \mathrm{~g}-10.74 \mathrm{mg} / 100 \mathrm{~g}$.
\end{abstract}

Keywords: Debittering, minerals, orange seed, phytochemicals, wheat flour

\section{Introduction}

Citrus is one of the most abundant crops in the world with oranges, grapefruits, lemons being the most common citrus fruits. Orange belongs to the Rutaceae family which comprises grapefruits, mandarins, limes, lemons, and oranges [1]. The seeds are usually embedded at the centre of the fruit, in direct contact with the juice sacs [2]. Sweet orange seed is a by-product of juice production and constitute environmental pollution when not disposed properly. The seeds are very worrisome waste capable of causing serious environmental pollution, but these wastes are promising materials in the food industries due to their nutritional and phytochemical properties. The orange seed is a potential source of minerals and phytochemicals. Minerals and phytochemicals play vital roles in sustaining good health.

Consumption of fruits and vegetables has attracted huge attention since many epidemiological and biochemical studies have consistently demonstrated a clear and significant positive alliance between regular intake of these natural food products and reduced rates of heart diseases, common cancers, aging and other degenerative diseases [3]. The protection properties of these fruits have been attributed to the presence of several minerals and phytochemicals. Phytochemicals are non - nutritive plant chemicals that have protective or disease preventive properties [4]. Phytochemicals act as antioxidants and protect cells against free radical damage, e.g. polyphenols, alkaloids etc [5]. They also help in reducing risk of cancer by inhibiting tumor production [6].

The consumption of citrus seeds is believed to confer some protection against diseases such as cardiovascular disease and cancer [7] [8] [9]. Orange seeds were reported to contain alkaloids, steroids, flavonoids, saponins, tannins, cardiac glycosides and terpenoids [2], orange seeds act as antioxidants and protect cells against free radical damage, because of its phytochemicals contents [5]. They may also help in reducing risk of cancer by inhibiting tumor production [6]. Flavonoid (limonene) which is found in citrus seeds serve as antioxidant, inhibit tumor formation, and decreases inflammation [4]. Limonene, one of the main constituents of orange, reduces the risk of mouth, skin, lungs, breast, stomach, and colon cancer [10].

Alkaloids have pharmacological application as anasthetics and central nervous system (CNS) stimulants, muscle relaxant, antibiotics, anti-cancer, anti-arrythmic and sedative [11]. Some of the general properties of saponins include formation of foams in aqueous solution, hemolytic activity and cholesterol binding properties and bitterness [12]. Saponins natural tendency to ward off microbes makes them good candidates for treating fungal and yeast infections [12]. These compounds serve as natural antibiotics, which help the body to fight infections and microbial invasion [12]. Consumption of saponin should be encouraged, because of their hypocholestoromic activity[4].

Flavonoids are the largest group of polyphenolic compounds found in higher plants and synthesized from the shikimic acid and malonic acid pathways [13]. Flavonoids intake has been inversely linked with coronary heart disease [4]. Flavonoids are another large family of protective phytochemicals found in fruits and vegetable [4]. Tannins may decrease protein quality by decreasing digestibility and palatability [4]. Reduction of 
tannin content in the dehulled flour is expected to improve its nutritional value because tannins form complexes with proteins and reduce their digestibility and palatability [14].

Iron deficiency is the most common nutritional disorder in the world [15]. According to WHO, around 0.8 million deaths can be attributed to iron deficiency each year [15]. In terms of the loss of healthy life, expressed in disability-adjusted life years (DALYs), iron-deficiency anemia results in 25 million DALYs lost [15]. Iron deficiency causes growth retardation, low birth weight, increased prenatal mortality, increased maternal morbidity and mortality [16]. Iron-deficiency anemia is also a serious public health problem in all countries comprising the Eastern Mediterranean Region, Middle East and North Africa Region [15]. Iron functions as hemoglobin in the transport of oxygen and function as essential components of enzymes involved in biological oxidation such as cytochromes [17].

The bitter fraction of orange fruit arises from a tetracyclic triterpenoid called limonin. The limonin is produced from limonic acid or limonin monolactone, which is found in the seeds and membranes of most Citrus fruits [18]. Limonin or its precursor is mainly in the seeds, including peels, albedo and segment wall of the orange fruit [19]. Bitterness due to limonin in a variety of Citrus products is a major problem of the worldwide citrus industry and causes significant negative impact on orange product processing. Excess bitterness affects the quality of many processed orange products. This results in significant loss of products due to rejection by consumers, thus, there is need to reduce the level of bitterness of orange seed.

Wheat flour is low in phytochemicals and mineral constituents. Sweet orange seed flour, however, has high levels of calcium, potassium and essential phytochemicals [20]. Sweet orange seed flour could be used to supplement wheat flour. The production of orange seed flour would not only increase the source of flour for food processing but would also act as a waste management strategy. The purpose of this investigation was to determine the effect of the debittering methods such as soaking, boiling and deffatting on the mineral and phytochemical composition of orange seed flour.

\section{Materials And Methods}

Sweet orange (Citrus sinensis) fruits were purchased from a local market in Enugu State, Nigeria.

\subsection{Preparation of debittered orange seed flour}

The fruits were cut into halves with a clean sharp knife and the seeds were removed and sundried at 34 $\pm 2{ }^{\circ} \mathrm{C}$, for $8 \mathrm{~h}$. The orange seed were cleaned with tap water. The orange seeds $(20 \mathrm{~kg})$ were soaked in tap water for $12 \mathrm{~h}$. Thereafter, the hydrated seeds were boiled for 40, 80, 120 and $160 \mathrm{~min}$, respectively. All samples were dehulled manually, winnowed, oven dried at $60{ }^{\circ} \mathrm{C}$ for $12 \mathrm{~h}$, ground with corolla hand grinding machine. The oils were extracted with ethanol in a soxhlet apparatus and milled. Flours were analyzed for bitterness by sensory evaluation, the $100 \%$ wheat flour served as control. The flow chart for the preparation of debittered orange seed flour is shown in figure 1.

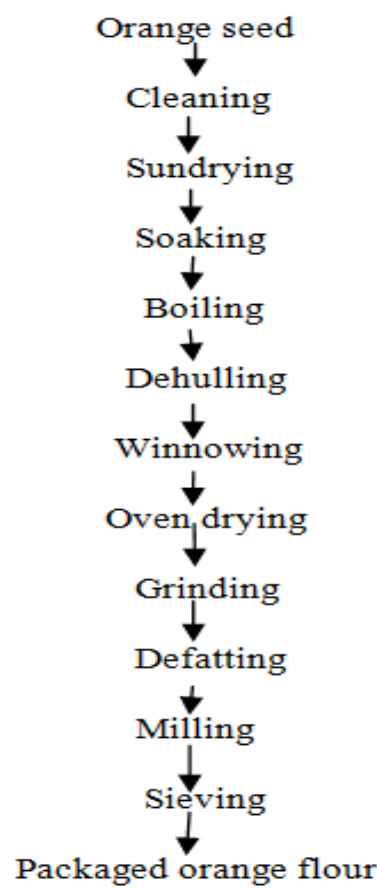

Fig 1. Processing of debittered orange seed flour 
Effect of Debittering Methods on the Minerals, and Phytochemical Properties of Orange (Citrus ..

\subsection{Determination of mineral composition}

Zinc was determined by wet ashing [21]. Potassium and sodium were determined using Atomic Absorption Spectrophotometry method as described by [22]. Calcium was determined using the method of [21].

\subsection{Determination of phytochemical and anti-nutrient composition}

Flavonoid was determined using the method of [23]. Alkaloid was determined using the method of [23]. Saponin was determined using the method of [21]. Tannin was determined using the method described by [24].

\section{Results And Discussion}

3.1 Effect of debittering methods on mineral composition of flours

The mineral contents of orange seed flour, debittered orange seed flour and wheat flour are shown in Table 1.

Table 1: Mineral composition of orange seed flours and wheat flour

\begin{tabular}{|l|l|l|l|l|l|}
\hline Flour & $\begin{array}{l}\text { Iron } \\
(\mathrm{Mg} / 100 \mathrm{~g})\end{array}$ & $\begin{array}{l}\text { Zinc } \\
(\mathrm{Mg} / 100 \mathrm{~g})\end{array}$ & $\begin{array}{l}\text { Calcium } \\
(\mathrm{Mg} / 100 \mathrm{~g})\end{array}$ & $\begin{array}{l}\text { Sodium } \\
(\mathrm{Ppm})\end{array}$ & $\begin{array}{l}\text { Potassium } \\
(\mathrm{Ppm})\end{array}$ \\
\hline Wheat flour & $1.14^{\mathrm{e}} \pm 0.01$ & $0.34^{\mathrm{d}} \pm 0.01$ & $18.23^{\mathrm{c}} \pm 0.09$ & $2.61^{\mathrm{e}} \pm 0.03$ & $6.28^{\mathrm{c}} \pm 0.01$ \\
\hline OSF & $18.54^{\mathrm{a}} \pm 0.70$ & $0.67^{\mathrm{a}} \pm 0.02$ & $476.90^{\mathrm{a}} \pm 0.97$ & $8.28^{\mathrm{a}} \pm 0.06$ & $28.02^{\mathrm{a}} \pm 0.02$ \\
\hline OSFB40 & $8.11^{\mathrm{b}} \pm 0.15$ & $0.61^{\mathrm{ab}} \pm 0.01$ & $171.92^{\mathrm{b}} \pm 0.87$ & $7.92^{\mathrm{ab}} \pm 0.07$ & $25.23^{\mathrm{b}} \pm 0.03$ \\
\hline OSFB80 & $6.18^{\mathrm{c}} \pm 0.15$ & $0.59^{\mathrm{b}} \pm 0.01$ & $170.56^{\mathrm{b}} \pm 0.16$ & $7.56^{\mathrm{bc}} \pm 0.21$ & $25.10^{\mathrm{b}} \pm 0.03$ \\
\hline OSFB120 & $1.94^{\mathrm{d}} \pm 0.14$ & $0.58^{\mathrm{b}} \pm 0.07$ & $158.06^{\mathrm{b}} \pm 0.48$ & $7.21^{\mathrm{cd}} \pm 0.01$ & $25.00^{\mathrm{b}} \pm 0.02$ \\
\hline OSFB160 & $0.85^{\mathrm{e}} \pm 0.06$ & $0.45^{\mathrm{c}} \pm 0.04$ & $152.01^{\mathrm{b}} \pm 0.18$ & $7.15^{\mathrm{d}} \pm 0.00$ & $24.46^{\mathrm{b}} \pm 0.02$ \\
\hline
\end{tabular}

Means within a column with the same superscript were not significantly different $(\mathrm{P}>0.05) . \mathrm{OSF}=$ orange seed flour, OSFB $40=$ orange seed flour boiled for $40 \mathrm{~min}, \mathrm{OSFB} 80=$ orange seed flour boiled for $80 \mathrm{~min}$, OSFB120 = orange seed flour boiled for $120 \mathrm{~min}$, and OSFB160 = orange seed flour boiled for $160 \mathrm{~min}$. All the treated flours were defatted.

The orange seed flour had the highest iron content of $18.54 \mathrm{mg} / 100 \mathrm{~g}$. The iron content of wheat flour was $1.14 \mathrm{mg} / 100 \mathrm{~g}$. The debittering methods reduced the iron content of the orange seed flour. The iron contents of the debittered orange seed flours ranged from $0.85 \mathrm{mg} / 100 \mathrm{~g}-8.11 \mathrm{mg} / 100 \mathrm{~g}$. Flour produced from $160 \mathrm{~min}$ boiled seed had the least Iron content $(0.85 \mathrm{mg} / 100 \mathrm{~g})$. Probably due to leaching boiling had negative effect on the iron content. Increased boiling time resulted in decreased iron content. Boiling reduced the content of iron in seeds [25].

There were significant $(\mathrm{p}<0.05)$ differences in the zinc contents which ranged from $0.34-6.73$ $\mathrm{mg} / 100 \mathrm{~g}$ with the highest value in the orange seed flour. Wheat flour had the lowest zinc content $(0.34$ $\mathrm{mg} / 100 \mathrm{~g}$ ). However, flours produced from 80 and $120 \mathrm{~min}$ boiled seeds had high value of zinc. Low zinc intake in young children increases the rate of diarrhea and acute lower respiratory infection and reduces linear growth and physical development [26]. Deficiencies of zinc in man include hypogonadism, growth failure, and impaired wound healing [27]. Zinc is essential for the function of many enzymes [28]. Zinc is required for maintenance of normal mobilization of vitamin A from the liver [28]. Low zinc intake results in hyponadism, dwarfism, low serum and red blood cell in humans and retarded growth [28]. In children, suffering from marginal zinc deficiency, impaired taste acuity, poor appetite and suboptimal growth were reversed with zinc supplementation [28]. As an antioxidant, Zinc is important to the immune, reproductive and central nervous systems and is present in many areas of the brain, particularly in the hippocampus and amygdala [29], influencing brain structure and function [30] [31]. Zinc deficiency ranging from slower wound healing to delayed physical and cognitive development [32]. Inadequate $\mathrm{Zn}$ in nutrition has been identified in both developing and developed countries, particularly in infants, pregnant and lactating women and older adults [33] [34] [30]. Zinc supplementation studies in infants and pregnant women have demonstrated benefits in terms of the physical health, growth rate and cognitive development of the infants and babies born to the mothers taking supplements [35] [36] [37].

There were significant differences in the calcium contents of the flour samples, which ranged from $18.23-476.90 \mathrm{mg} / 100 \mathrm{~g}$ with the highest value in the orange seed flour $(476.90 \mathrm{mg} / 100 \mathrm{~g})$. Wheat flour had the lowest calcium content of $18.23 \mathrm{mg} / 100 \mathrm{~g}$. However, the debittering methods reduced the calcium content of orange seed flour. There were no significant differences in the calcium contents of the debittered orange seed flours, values varied from $152.01-171.92 \mathrm{mg} / 100 \mathrm{~g}$. Calcium is an essential nutrient needed to help muscles to contract, blood to clot and nerves to carry message [28]. Calcium also helps build bones and teeth and keep them strong. Poor calcium intake is a risk factor for osteoporosis, a crippling disease. Calcium is the major component of bone and assists in teeth development [38]. 
The sodium contents of the flours ranged from $2.61-8.28 \mathrm{ppm}$. There were significant $(\mathrm{p}<0.05)$ differences in the sodium content of the flour samples. The orange seed flour recorded the highest sodium content of $8.28 \mathrm{ppm}$, wheat flour had the least sodium content of $2.61 \mathrm{ppm}$. Sodium ion acts in concert with other electrolytes, to regulate the osmotic pressure and to maintain the appropriate water balance of the body and acid-base balance $(\mathrm{pH})[28]$.

The potassium content of the flours varies from $6.28-28.02 \mathrm{ppm}$. Orange seed flour had the highest value of $28.02 \mathrm{ppm}$ while wheat flour had calcium content of $6.28 \mathrm{ppm}$. The debittering methods reduced the potassium content of the dehulled orange seed flour. However, there was no significant difference in the potassium contents of the various debittered orange seed flours, values ranged from $24.46-25.23 \mathrm{ppm}$. The decrease in potassium content may be due to leaching in the cooking water during boiling. Potassium plays important roles in the maintenance of normal glucose tolerance and in the release of insulin from cells of islets of langerhans [39]. The high level of potassium is of nutritional benefit especially for patient with high blood pressure [40]. Potassium plays an important role in normal cellular function and metabolism, such as regulating the activity of nerves and muscles, maintaining proper electrolyte balance and acid-base balance in the body, preventing hyper-acidity, controlling high blood pressure and also reducing risk of stroke [28]. Potassium ion acts as a catalyst in the intracellular fluid, in energy metabolism and is required for carbohydrate and protein metabolism [28].

Boiling drastically reduced the mineral and antinutritional composition of the flour [41]. The decrease in the minerals appeared to be more pronounced for iron and calcium in the debittered orange seed flours when compared to the orange seed flour.

\subsection{Phytochemicals composition of flour}

Table 2: Phytochemical composition of orange seed flours and wheat flour

\begin{tabular}{|l|l|l|l|l|}
\hline Flour & $\begin{array}{l}\text { Alkaloids } \\
(\%)\end{array}$ & $\begin{array}{l}\text { Saponins } \\
(\%)\end{array}$ & $\begin{array}{l}\text { Flavonoids } \\
(\%)\end{array}$ & $\begin{array}{l}\text { Tannins } \\
(\mathrm{mg} / 100 \mathrm{~g})\end{array}$ \\
\hline Wheat & $1.15^{\mathrm{c}} \pm 0.06$ & $\mathrm{Nd}$ & $0.55^{\mathrm{d}} \pm 0.07$ & $0.94^{\mathrm{c}} \pm 0.12$ \\
\hline Orange seed & $6.95^{\mathrm{a}} \pm 0.68$ & $0.38^{\mathrm{a}} \pm 0.01$ & $29.17^{\mathrm{a}} \pm 0.66$ & $10.74^{\mathrm{a}} \pm 1.12$ \\
\hline OSFB40 & $6.37^{\mathrm{ab}} \pm 0.14$ & $0.31^{\mathrm{b}} \pm 0.01$ & $12.11^{\mathrm{b}} \pm 0.48$ & $8.25^{\mathrm{b}} \pm 0.26$ \\
\hline OSFB80 & $6.28^{\mathrm{ab}} \pm 0.04$ & $0.28^{\mathrm{c}} \pm 0.01$ & $11.91^{\mathrm{b}} \pm 0.21$ & $8.25^{\mathrm{b}} \pm 0.49$ \\
\hline OSFB120 & $5.81^{\mathrm{b}} \pm 0.53$ & $0.15^{\mathrm{d}} \pm 0.02$ & $11.69^{\mathrm{b}} \pm 0.80$ & $7.34^{\mathrm{b}} \pm 0.92$ \\
\hline OSFB160 & $5.70^{\mathrm{b}} \pm 0.60$ & $0.14^{\mathrm{d}} \pm 0.01$ & $9.72^{\mathrm{c}} \pm 0.04$ & $7.34^{\mathrm{b}} \pm 0.60$ \\
\hline
\end{tabular}

Means within a column with the same superscript were not significantly different $(\mathrm{P}>0.05) . \mathrm{OSF}=$ orange seed flour, OSFB $40=$ orange seed flour boiled for $40 \mathrm{~min}$, OSFB80 $=$ orange seed flour boiled for $80 \mathrm{~min}$, OSFB120 = orange seed flour boiled for $120 \mathrm{~min}$, and OSFB160 = orange seed flour boiled for $160 \mathrm{~min}$

All the phytochemical in the orange seed flours where higher than in wheat flour in Table 2. Significant differences existed in the phytochemical contents. Alkaloids level in the flours ranged from $1.15-6.95 \%$. Orange seed flour had the highest alkaloid content of $6.95 \%$. Wheat flour had the lowest value of alkaloids $(1.15 \%)$. The debittering methods reduced the alkaloids level significantly $(\mathrm{p}<0.05)$. However, there were no significant differences in the alkaloids contents of debittered orange seed flours. The presence of alkaloids in the orange seeds indicates that the orange seed should not be eaten raw. Most alkaloids are known for their pharmacological effects rather than their toxicity, however, when alkaloids occur in high levels in foods, they cause gastro-intestinal upset and neurological disorders [42]. Alkaloids are best known as drugs, however, several occurs in foods, potential foods or food contaminants. Appropriate screening of certain common food commodities and foods under development from new sources is important in quality assurance so that risks may be evaluated or eliminated [28]. Phytochemicals may display their health protective effects in diverse ways.

Saponin was absent in wheat flour. Saponin contents of the flour ranged from $0-0.38 \%$. The highest value was showed by the orange seed flour $(0.38 \%)$. Debittering methods reduced the saponin concentration. The saponin concentration reduced in the orange seed flour with increased in boiling time of the seed. The saponins contents of the debittered orange seed flours varied from $0.14-0.31 \%$. There was generally a gradual decrease in the saponin contents of the debittered orange seed flours with boiling time. Saponin is an anti-nutritional factor whose toxicological effects should be balanced with its benefits. Some of the general properties of saponins include formation of foams in aqueous solution, hemolytic activity and cholesterol binding properties and bitterness [12]. Consumption of saponin should be encouraged, because of their hypocholestoromic activity [4]. The flavonoid concentrations were higher in the orange seed flour and debittered orange seed flours than in the wheat flour. The flavonoid contents of the flours ranged from $0.55 \%-29.17 \%$. The orange seed flour had the highest value $(29.17 \%)$ while the wheat flour had the lowest value $(0.55 \%)$. However, the debittering methods reduced the flavonoid contents. The flavonoid contents of the debittered orange seed flours ranged from $9.72-$ 
$12.11 \%$. Flavonoid concentrations were significantly $(\mathrm{p}<0.05)$ affected by boiling. Flavonoids are destroyed by heat processing methods like drying, roasting and boiling [43].

There were significant $(\mathrm{p}<0.05)$ differences in the tannin concentration of the flour samples. The tannins values varied from $0.94-10.74 \mathrm{mg} / 100 \mathrm{~g}$. The orange seed flour had the highest value $(10.74 \mathrm{mg} / 100 \mathrm{~g})$ while the wheat flour had the least value $(0.94 \%)$. The debittering methods reduced the tannins concentration of the orange seed flour. The tannins contents of the debittered orange seed flour ranged from $7.343-8.25$ $\mathrm{mg} / 100 \mathrm{~g}$. There were no significant differences in the tannins contents of the debittered orange seed flours. The reduction of tannin contents of the boiled orange seeds was in agreement with the earlier report that processing methods such as soaking, boiling and fermentation lowered the tannin contents of foods [44]. The decrease in the levels of tannin during cooking may be due to the thermal degradation and denaturation of the tannin as well as the formation of insoluble complexes [45]. Tannin affects the nutritive value of food products by forming complex with protein (both substrate and enzyme) thereby inhibiting digestion and absorption [46].

Thermal processing can affect the phytochemicals by thermal breakdown that affect the integrity of the cell structure which then results in the migration of components leading to losses by leakage or breakdown by various chemical reactions involving enzymes, light and oxygen [47]. Boiling, soaking, sun drying, deffating, and oven drying resulted in reduction of all the phytochemicals analyzed in this study. Most anti-nutritional factors in food can be reduced by proper application of heat [48] [49]. The reduction of phytochemical/antinutrients increased as boiling period increased [49]. The determination of the anti-nutritional substances was of interest because of their toxicity in orange seeds, and negative effects on mineral bioavailability.

Soaking prior to boiling reduced the concentrations of the flavonoids, alkaloids, saponins and tannins. Soaking in water or periodic changing of the water during soaking, would give a more appreciable reduction in the phytochemicals concentrations. These processes are used for detoxification and debittering of the seeds [50].

\section{Conclusion}

The debittered orange seed flours were higher in calcium, iron, zinc and potassium content than wheat flour. However, the minerals decreased with increased in the boiling time of the seeds. Flours produced from debittered orange seed flour were richer in phytochemical constituents such as flavonoids, tannins, saponins and alkaloids than in wheat flour. However, the debittering methods reduced the phytochemical content of orange seed flour and its bitter taste.

\section{Acknowledgement}

I deeply appreciate Dr. and Mrs. Daniel Emojorho for their financial and moral assistance throughout the period of this work.

\section{Reference}

[1]. I. J. Karoui, and B. Marzouk, (2013). Characterization of bioactive compounds in Tunisian bitter orange (Citrus aurantium L.) peel and juice and determination of their antioxidant activities, Biomedical Research International 2013, (http://dx.doi.org/10.1155/2013/345415

[2]. E.I. Oikeh, K. Oriakhi, and E. S. Omoregie, Proximate analysis and photochemical screening of Citrus sinensis fruit wastes. The Bioscientist, 1(2), 2013, 164-170.

[3]. K. A. Steinmetz, and J. D. Potter, Vegetables, fruits and cancer prevention: a review. Journal of the American Dietetic Association, 96, 1996, 1027-1039.

[4]. I. A. Onimawo, and P. I. Akubor, Food Chemistry: Integrated Approach with Biochemical Background, 2nd Edition, (Agbowo, Ibadan, Nigeria ,Jotal printing press) $287-295$.

[5]. E. S. Omoregie, and A. U. Osagie, Antioxidant properties of methanolic extracts of some Nigerian plants on nutritionally stressed rats. Nigerian Journal of Basic and Applied Science, 20(1), 2012, 7-20.

[6]. T. P. A. Devasagayam, J. C. Tilak, K. K. Boloor, K. S. Sane, S. S. Ghaskadbi, and R. D. Lele, Free radicals and antioxidants in human health: current status and future prospects, Journal of Association of Physicians of India 52, $2004,794-804$.

[7]. K. Baghurst, The health benefits of citrus fruits. CSIRO Health Sciences and Nutrition full report.( Sydney, Australia, Horticulture Australia Ltd, 2003).

[8]. R. Guimaraes, L. Barros, J. C. Barreira, M. J. Sousa, A. M. Carvalho, and I. C. Ferreira, Targeting excessive free radicals with peels and juices of citrus fruits: grapefruit, lemon, lime and orange. Food and Chemical Toxicology, 48, 2010,99 - 106.

[9]. O. Atolani, J. Omere, C. A. Otuechere, and A. Adewuyi, Antioxidant and cytotoxicity effects of seed oils from edible fruits. Journal of Acute Disease 1 (2), 2012, 130-134.

[10]. P. Milind, and D. Chaturvedi, Orange: Range of Benefit. International Research Journal of Pharmacy, 3(7), 2012,59 - 63.

[11]. H. A. Madziga, S. Sanni, and U. K. Sandabe, Phytochemical and elemental analysis of Acalypha wilkesiana leaf. Journal of American Science, 6 (11), 2010, 510 - 514.

[12]. O. A. Sopido, J. A. Ahiniyi, and J. U. Ogunbanosu, Studies on certain characteristics of extracts of barke of pansinystalia macruceras (K. Schem.) Pierve Exbeille. Global Journal of Pure and Applied sciences, 6, 2000, 83-87.

[13]. H. P. V. Rupasinghe, The role of polyphenols in quality, post harvest handling and processing of fruits. Ed: Paliyath, G, Lurrie, S, Murr, D. Handa A. Post Harvest Biology and Technology of Fruits, Vegetables and Flowers. (Wiley-Blackwell Publishers, 2008). 1: $260-281$.

[14]. O. U. Eka, "The Chemical Composition of Yam Tubers". In: Advances in Yam Research. The Biochemistry and Technology of Yam Tubers. Osuji, G. (ed). Biochemical Society of Nigeria, Enugu, Nigeria. 1, 1985,51 - 75. 
Effect of Debittering Methods on the Minerals, and Phytochemical Properties of Orange (Citrus ..

[15]. M. I. Ibrahium, and A. E. Hegazy, Antioxidant activities of orange peel extracts.

World Applied Sciences Journal, 18 (5): 2012, $684-688$.

[16]. L. H. Allen, Pregnancy and iron deficiency: effects of the newborns - unsolved issues. Nutrition Reviews, 55 , $1997: 91$ - 101.

[17]. V. K. Malhotra, (1998). Biochemistry for Students. Tenth Edition. (Jaypee Brothers Medical Publishers (P) Ltd, New Delhi, India).

[18]. S. S. Kulwant, and K. S. Minhas, Handbook of Fruits and Fruit Processing: Oranges and Citrus Juices. (Blackwell Publishing, Oxford, United Kingdom, 2006) pp. 322 - 325.

[19]. LalKaushal, B. B. and Thakur, N. K. (2001). Pilot scale debittering of kinnow juice using adsorbent amberlite XAD-16. Journal of Science and Industrial Research, 60, 2001, 896 - 899.

[20]. M. I. Akpata, and P. I. Akubor, Chemical composition and selected functional properties of sweet orange (Citrus sinensis) seed flour. Plant Foods for Human Nutrition, 54, 1999, 353 - 62.

[21]. AOAC, Official methods of analysis 18th Ed. (Association of Official Analytical Chemists, Washington, D.C., USA, 2010).

[22]. C. S. James, (1996). Analytical Chemistry of foods. (Blackie Academic and Professionals, New York, 1996) $267-496$.

[23]. B. A. Boham, and A. C. Kocipai, Flavonoids and condensed tannins from leaves of Hawaiian vaccinium vaticulatum and V. calycinium. Pacific Science, 48, 1974, 458-463.

[24]. J. R. Harborne, Phytochemical methods: A guide to modern techniques of plant analysis. (Chapman and Hall Ltd, London, 1973) 49-55.

[25]. D. Pearson, Chemical analysis of food. $7^{\text {th }}$ Ed, (Livingstone London,churchhill, 1976)

[26]. A. V. Ritva, R. E. Christian, J. C. Maria, B. Grecob, and A. R. Patricia, Effects of roasting and boiling of quinoa, kiwicha and kaniwa on composition and availability of minerals in vitro. Journal of Science of Food and Agriculture, 90, $2010,2068-2073$.

[27]. L. E. Daly, P. N. Kirke, A. Molloy, D. G. Weir, and J. M. Scott, Folate levels and neural tube defects. Implications for prevention. The Journal of the American Medical Association, 274, 1995, 1698-702.

[28]. P. Murray, Y. Ge, and W. H. Hendershot, Evaluating three trace metal contaminated sites: a field and laboratory investigation. Environmental Pollution, 107, 2000, $127-35$.

[29]. R. Macrae, R. K. Robinson, and M. J. Sadler, (1993). Encyclopaedia of Food Science, Food Technology and Nutrition. (Academic Press inc., San Diego, CA, 1993). 5: 3126 - 3131.

[30]. A. Takeda, Movement of zinc and its functional significance in the brain, Brain Research Reviews, 34, 2000, $137-148$.

[31]. H. H. Sandstead, Causes of iron and zinc deficiencies and their effects on brain. Journal of Nutrition, 130, $2000,347-349$.

[32]. H. H. Sandstead, Zinc is essential for brain development and function. Journal of Trace Elements in Experimental Medicine, 16, $2003,165-173$.

[33]. M. Hambidge, (2000). Human zinc deficiency. Journal of Nutrition, 130, 2000, $1344-1349$.

[34]. R. R. Briefel, K. Bialostosky, J. Kennedy-Stephenson, M. A. Mc-Dowell, R. B. Ervin, and J. D. Wright, Zinc intake of the U.S. population: findings from the third national health and nutrition examination survey, 1988-1994. Journal of Nutrition 130, 2000, $1367-1373$.

[35]. J. G. Penland, Behavioral data and methodology issues in studies of zinc nutrition in humans. Journal of Nutrition 130, $2000,361-$ 364.

[36]. M. M. Black, Zinc deficiency and child development. The American Journal of Clinical Nutrition, 68, $1998,464-469$.

[37]. S. Bhatnagar, and S. Taneja, Zinc and cognitive development. British Journal of Nutrition, 85, 2001, 139-145.

[38]. M. J. Salgueiro, M. B. Zubillaga, A. E. Lysionek, R. A. Caro, R. Weill, and J. R. Boccio, The role of zinc in the growth and development of children. Nutrition Journal, 18, 2002, 510-519.

[39]. T. Brody, Nutritional biochemistry. The effect of heat treatments on the nutritional values of different crops. (San Diego, CA: Academic Pres, 1994)

[40]. K. A. Choudhary, and N. G. Bandyopadhyay, Preliminary studies on the inorganic constituents of some indigenous hyperglycaemic herbs on oral glucose tolerance test. Journal of Ethnopharmacology, 64, 1999, 179 - 184.

[41]. J. N. Enwere, Foods of plant origin. (Afro orbis Publishing Limited, Nsukka, Nigeria, 1998) 64 - 124.

[42]. A. O. Abiodun, and A. B. Adepeju, Effect of processing on the chemical pasting and antinutritional composition of bambara nut (Nigra subtlenanca L. verde) flour. Advanced Journal of Food Science and Technology, 3, 2011, 224 - 227.

[43]. J. C. Okaka, N. J. Enoch, N. C. Okaka, Human Nutrition. An Integrated Approach, (Enugu State University of Technology Publication, Enugu, 1992)130-152.

[44]. M. Mc Williams, (1979). Food Fundamentals (John Wiley and sons Inc. New York U.S.A. 1979) 125 - 130.

[45]. C. I. Jude, C. I. Catherine, and M. I. Ngozi, Chemical Profile of Tridax procumbens Linn. Pakistan Journal of Nutrition, 8, 2009, 548-550.

[46]. A. Kataria, B.M. Chauhan, and D. Punia, Antinutrients and protein digestibility (in vitro) of mungbean as affected by domestic processing and cooking. Food Chemistry, 3, 1989, 9-17.

[47]. B. A. Osuntogun, S. R. A. Adewusi, A. Adewusi, J. O. Ogundiwin, and C. C. Nwasike, Effect of cultivar, steeping, and malting on tannin, total polyphenol, and cyanide content of Nigerian sorghum. Cereal Chemistry, 66, 1989, 87-89.

[48]. M. W. Davey, V. M. Montagu, D. Inze, M. Sanmartin, A. Kanellis, and N. Smirnoff, Plant L-ascorbic acid: Chemistry, function, metabolism, bioavailability and effects of processing. Journal of the Science of Food and Agriculture, 80, $2000,825-860$.

[49]. T. F. Balogun, F. G. Kaankuka, and G. S. Bawa, Effect of boiling full fat soyabeans on its amino acid profile and on performance of pigs. Nigerian Journal of Animal Production, 28, 2001, 45-51.

[50]. V. C. Ezeocha, and P. C. Ojimelukwe, The impact of cooking on the proximate composition and anti-nutritional factors of water yam (Dioscorea alata). Journal of Stored Products and Postharvest Research, 3: (13), 2012, 172 - 176.

[51]. I. S. Asogwa, and J. C. Onweluzo, Effects of processing methods on the chemical composition of flour, moinmoin and akara from Mucuna pruriens. Journal of Tropical Agriculture, Food, Environment and Extension, 9, 2010, $200-208$. 